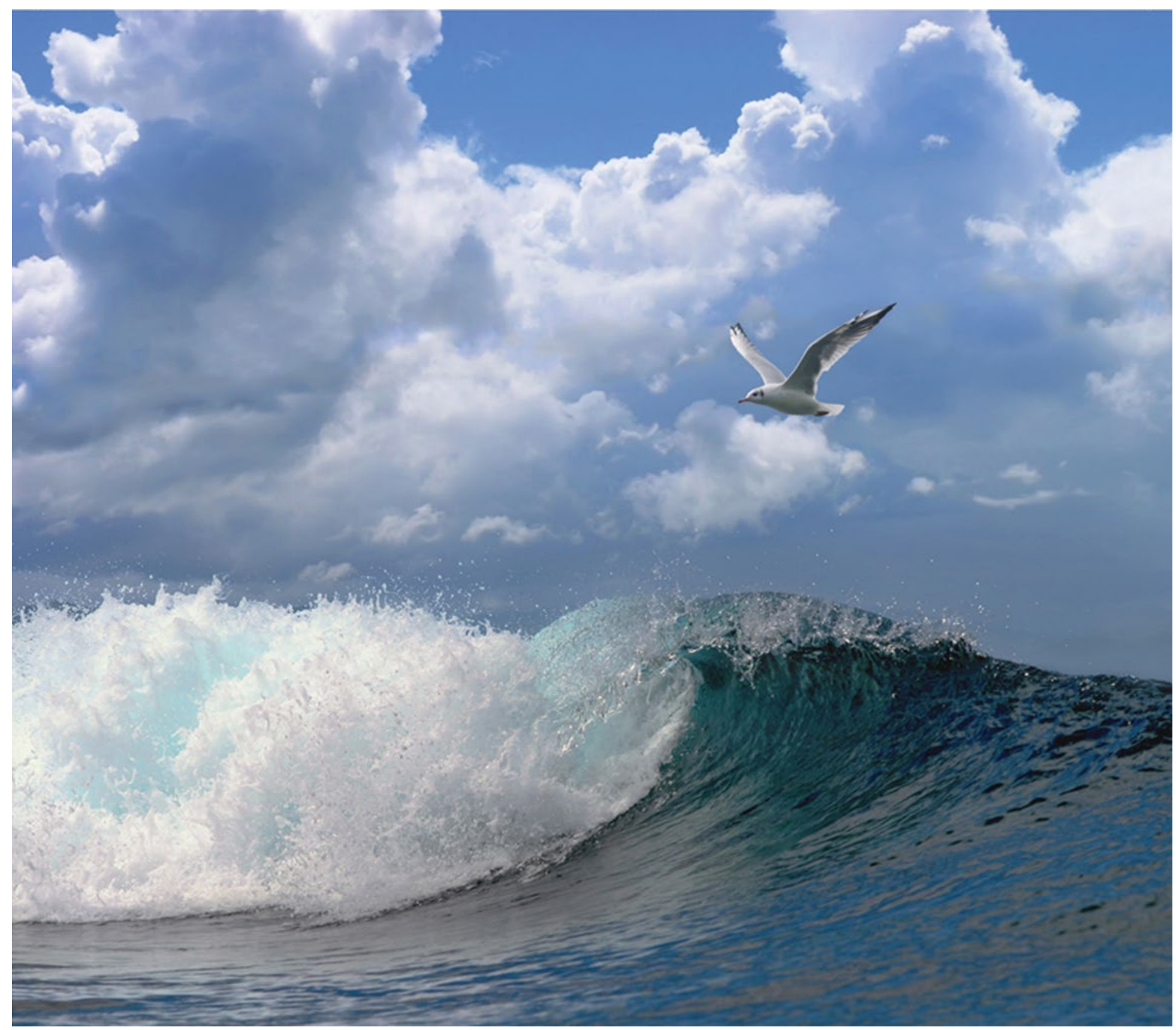

\title{
Aalonderzoek Hoogheemraadschap van Delfland: groei en verspreiding van rode aal (Anguilla anguilla) 2020
}

Een datarapportage 


\section{Aalonderzoek Hoogheemraadschap van Delfland: groei en verspreiding van rode aal (Anguilla anguilla) 2020}

Een datarapportage 
Keywords: Rode aal, groeisnelheid, verspreiding, Delfland, PIT-tag

Opdrachtgever: Hoogheemraadschap van Delfland

T.a.v. W. van der Ende

Postbus 3061

2601 DB Delft

Dit rapport is gratis te downloaden van https://doi.org/10.18174/535183.

Wageningen Marine Research verstrekt geen gedrukte exemplaren van rapporten.

Wageningen Marine Research is ISO 9001:2015 gecertificeerd.

(C) Wageningen Marine Research

Wageningen Marine Research, instituut binnen de rechtspersoon Stichting

Wageningen Research, hierbij

vertegenwoordigd door

Dr. ir. J.T. Dijkman, Managing director

KvK nr. 09098104,

WMR BTW nr. NL 8113.83.696.B16.

Code BIC/SWIFT address: RABONL2U

IBAN code: NL 73 RABO 0373599285
Wageningen Marine Research aanvaardt geen aansprakelijkheid voor gevolgschade, noch voor schade welke voortvloeit uit toepassingen van de resultaten van werkzaamheden of andere gegevens verkregen van Wageningen Marine Research. Opdrachtgever vrijwaart Wageningen Marine Research van aanspraken van derden in verband met deze toepassing.

Alle rechten voorbehouden. Niets uit deze uitgave mag weergegeven en/of gepubliceerd worden, gefotokopieerd of op enige andere manier gebruikt worden zonder schriftelijke toestemming van de uitgever of auteur. 


\section{Inhoud}

$\begin{array}{lr}\text { Samenvatting } & 4\end{array}$

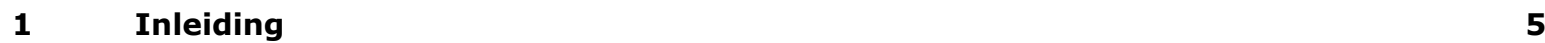

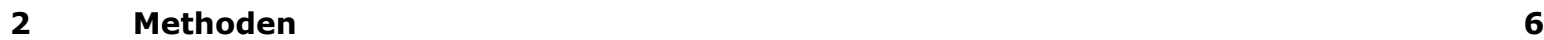

2.1 Studiegebied $\quad 6$

$\begin{array}{lll}2.2 & \text { Vaststellen groei } & 6\end{array}$

$\begin{array}{lll}2.3 & \text { Werkzaamheden en diefstal fuiken } 2020 & 7\end{array}$

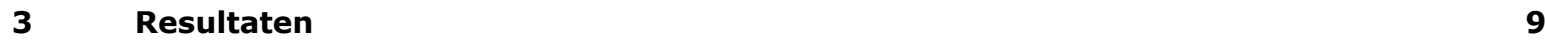

3.1 Terugvangsten $\quad 9$

3.2 Lengtemetingen en groeisnelheid 11

$4 \quad$ Conclusies en aanbevelingen $\quad 15$

$\begin{array}{llr}5 & \text { Kwaliteitsborging } & 16\end{array}$

$\begin{array}{lr}\text { Literatuur } & 17\end{array}$

$\begin{array}{lr}\text { Verantwoording } & 18\end{array}$

$\begin{array}{llr}\text { Bijlage } 1 & \text { Lengte frequentie alen } & 19\end{array}$

$\begin{array}{llr}\text { Bijlage } 2 & \text { Coördinaten fuiklocaties } & 20\end{array}$ 


\section{Samenvatting}

Het Hoogheemraadschap van Delfland (HHD) heeft de afgelopen jaren bijgedragen aan het verbeteren van de overlevingskansen van Europese aal (Anguilla anguilla) in het beheergebied. Zo is er geïnvesteerd in het vispasseerbaar maken van kunstwerken. Ook is met de lokale beroepsvisserij overeengekomen te stoppen met aalvisserij in het gehele beheergebied van Delfland voor de periode 2017 t/m 2022 en te investeren in de ontwikkelingen van aal in het gebied door o.a. het doen van onderzoek.

De huidige studie betreft een merk-terugvangstexperiment van rode aal in vijf deelgebieden in boezemwater van HHD: Berkelse Zweth (BZ), Nieuwe Water (NW), Vlaardingse Vaart (VV), Boonervliet (BV) en het Verversingskanaal (VK) nabij gemaal Schoute. Het doel van het onderzoek is het vaststellen van variatie in groei en verspreiding van rode aal in het beheergebied. In 2017 (jaar 1) en 2018 (jaar 2) zijn in totaal 1008 rode alen van een $12 \mathrm{~mm}$ PITtag voorzien. Het onderzoek wordt in het veld uitgevoerd door visserijbedrijf $W$. den Boer met ondersteuning van vrijwilligers van de Hengelsportvereniging SVBD (Sport Visserij Belangen Delfland), GHV / Groene Hart en medewerkers van het Hoogheemraadschap van Delfland. Wageningen Marine Research begeleidt het onderzoek. Deze rapportage betreft een verslaglegging van het vierde onderzoeksjaar (jaar 4, 2020). De werkzaamheden van jaar 1, 2 en 3 zijn in aparte rapportages gepubliceerd. In het vierde jaar is geprobeerd om de alen die in jaar 1 en jaar 2 zijn gemerkt terug te vangen en opnieuw op te meten. Het onderzoek wordt nog twee jaren voortgezet (2021-2022).

Over alle jaren heen zijn 296 alen één (= 216 alen) of meer keer teruggevangen, incl. terugvangsten een aantal dagen na merken. In totaal zijn er in 202096 verschillende alen teruggevangen van de 1008 gemerkte rode alen (9.5\%). Veertien alen zijn twee keer gevangen, één aal drie keer, drie alen vier keer, één aal vijf keer en één aal zes keer binnen het onderzoek van 2020. Het totaal aantal terugvangsten in 2020 komt daarmee op 130 stuks (BO/VV: 55 stuks, BZ: 17 stuks, NW: 3 stuks en VK: 55 stuks).

De groeisnelheid over alle onderzoeksjaren van de vissen die zijn teruggevangen ligt rond de $41.7 \mathrm{~mm}$ per jaar en er is variatie tussen de gebieden. De gemiddelde groeisnelheid over alle jaren bij het Nieuwe Water is het hoogst $(59.8 \mathrm{~mm}$ per jaar). De laagste gemiddelde groei over alle jaren wordt gemeten in het Verversingskanaal (31.3 mm/jaar), gevolgd door de Boonervliet/Vlaardingse Vaart (40.7mm/jaar) en Berkelse Zweth ( $50.9 \mathrm{~mm} / \mathrm{jaar}$ ).

In het jaar 2020 zijn helaas diverse fuiken gestolen op verschillende locaties. Dit verdient de aandacht in de aankomende twee jaren om trefkans op gemerkte alen groot te houden. Deze rapportage betreft een tussenrapportage, een data rapportage. In de aankomende jaren wordt het onderzoek voortgezet en zal in 2022 afgesloten worden met een uitgebreidere rapportage en analyses. 


\section{$1 \quad$ Inleiding}

Het Hoogheemraadschap van Delfland (HHD) heeft de afgelopen jaren bijgedragen aan het verbeteren van de overlevingskansen van Europese aal in het beheergebied. $\mathrm{Er}$ is geïnvesteerd in het vispasseerbaar maken van kunstwerken en het verbeteren van de (ecologische) waterkwaliteit. Ook is met de lokale beroepsvisserij overeengekomen te stoppen met aalvisserij in het gehele beheergebied van Delfland voor de periode $2017 \mathrm{t} / \mathrm{m} \mathrm{2022}$. Het is echter onbekend hoeveel glasaal het beheergebied op natuurlijke wijze binnenkomt, waar de aal heen gaat en hoe groot het aalbestand is. Delfland heeft dan ook besloten om in de periode 2017 t/m 2022 onderzoek te doen naar de intrek van glasaal (Griffioen et al. 2018 ) en de aalpopulatie in het beheergebied. De beroepsvisserij wordt betrokken bij deze onderzoeken.

Een gezonde aalpopulatie is afhankelijk van verschillende factoren zoals vrije migratie tussen opgroei,en paaigebieden. Het Hoogheemraadschap van Delfland wil investeren in deze vrije migratie en daarnaast ook de opgroeigebieden in hun beheer goed onderhouden. Goed gefaciliteerde intrek van glasaal, een goede leefomgeving voor rode aal en effectieve uittrekmogelijkheden van volwassen schieraal binnen Delfland zal bijdragen aan de lokale, maar ook de algehele Europese aalpopulatie.

Deze studie betreft een merk-terugvangstexperiment van rode aal in vijf deelgebieden in boezemwateren van HHD. Het doel van het onderzoek is het vaststellen van variatie in groei en verspreiding van rode aal. Deze rapportage betreft een verslaglegging (datarapportage) van het vierde onderzoeksjaar (jaar 4). Het onderzoek wordt voortgezet met het (terug)vangen van rode aal in jaar 5 en 6 (2021-2022).

Dit onderzoek wordt begeleid door Wageningen Marine Research (WMR) en in het veld uitgevoerd door visserijbedrijf $W$. den Boer met ondersteuning van vrijwilligers van de Hengelsportvereniging SVBD (Sport Visserij Belangen Delfland), GHV / Groene Hart en medewerkers van het Hoogheemraadschap van Delfland (HHD). De vrijwilligers van de SVBD, GHV / Groene Hart en medewerkers van Hoogheemraadschap van Delfland helpen niet alleen mee met het onderzoek, maar zorgen er ook voor dat er toezicht is bij alle veldwerkzaamheden. Door de COVID-19 pandemie is het onderzoek in 2020 uitgevoerd W. den Boer en Wil van der Ende (HHD).

Doel van het onderzoek:

Onderzoek naar de variatie in groeisnelheid en verspreiding van rode aal in het gebeid van HHD.

\section{Onderzoeksvraag:}

Wat is de groeisnelheid van (rode) aal in het beheergebied van HHD en wat is de variatie tussen deelgebieden? Wat is de omvang van de rode aalpopulatie in de onderzochte deelgebieden van HHD en is er meer inzicht te krijgen in de migratieroutes van de aal in het beheergebied?

Deze rapportage gaat voornamelijk in op een overzicht van de data verzameld in 2020 . 


\section{Methoden}

\section{$2.1 \quad$ Studiegebied}

In het beheergebied van HHD werd in 2017 en 2018 met behulp van fuiken rode aal gevangen in vijf gebieden in boezemwater (Figuur 1). De rode alen werden verdoofd in een oplossing van $0.5 \mathrm{ml} / \mathrm{L} 1$ phenoxy ethanol. Vervolgens werden de alen gemerkt met een $12 \mathrm{~mm}$ HDX-PITtag die met een naald wordt ingebracht in de rugspier naast de rugvin. Elke tag heeft een unieke code. De code wordt afgelezen met een manual PITtag reader. Het plaatsen van de fuiken en het zetten van de $12 \mathrm{~mm}$ PITtags is, na instructie van WMR in het veld voor het zetten van de PITtags en het vrijgeven van een ontheffing, zelfstandig uitgevoerd door visserijbedrijf W. den Boer. De rode alen werden (verdoofd) gemeten tot op één decimaal in een V-vormige aalmeetbak. In $2017(n=336)$ en $2018(n=672)$ zijn in totaal 1008 rode alen gemerkt met een PITtag. In vervolg jaren zijn geen rode alen meer gemerkt met een PITtag; het aantal van 1008 gemerkte rode alen wordt voldoende geacht om voldoende groeigegevens te verzamelen. Op foto 1-4 zijn ter indicatie enkele handelingen van het (terug)vangen en meten weergegeven.

Binnen de studie zijn de deelgebieden Vlaardingse Vaart en Boonervliet samengevoegd, omdat de wateren met elkaar in verbinding staan én de fuiken relatief dicht bij elkaar staan (Figuur 1). Ten opzichte van de voorgaande rapportage (Griffioen and Schilder 2018) zijn, op basis van nieuw verkregen data in 2020, een aantal aanpassingen doorgevoerd in de database of is data verwijderd door onduidelijkheden op veldformulieren.

\subsection{Vaststellen groei}

Van de terugvangsten wordt per aal de lengte opgemeten (verdoofd). Doordat sommige alen meerdere malen wordt teruggevangen wordt er binnen deze rapportage een 'groeijaar' vastgesteld. Dit is de groei in $\mathrm{mm}$ tussen twee terugvangsten in twee aparte jaren (circa 365 dagen groei). Om de groei van een aal te bepalen is de lengte $(\mathrm{mm})$ op het moment van merken afgetrokken van de lengte op het moment van terugvangen. De groeisnelheid ( $\mathrm{mm} / \mathrm{jaar}$ ) is vervolgens bepaald door het lengteverschil te delen door het aantal dagen tussen merk en terugvangst x 365 dagen. Vervolgens is een gemiddelde groeisnelheid bepaald per onderzoeksjaar voor elke unieke aal om te voorkomen dat alen die meerdere malen zijn teruggevangen oververtegenwoordigd zijn. Als een aal in het merkjaar al is teruggevangen wordt dit niet opgenomen in de berekeningen. Met andere woorden de groeisnelheid wordt pas bepaald als aantal dagen tussen merken en terugvangen groter is dan 60 dagen. In de rapportage is ook een relatieve groei bepaald waarbij de gemeten lengte $(\mathrm{mm})$ bij terugvangst is gedeeld door de lengte op het moment van merken.

Een lengte-frequentie grafiek van de rode alen die zijn gevangen maar geen merk hadden is gegeven in de appendix. 


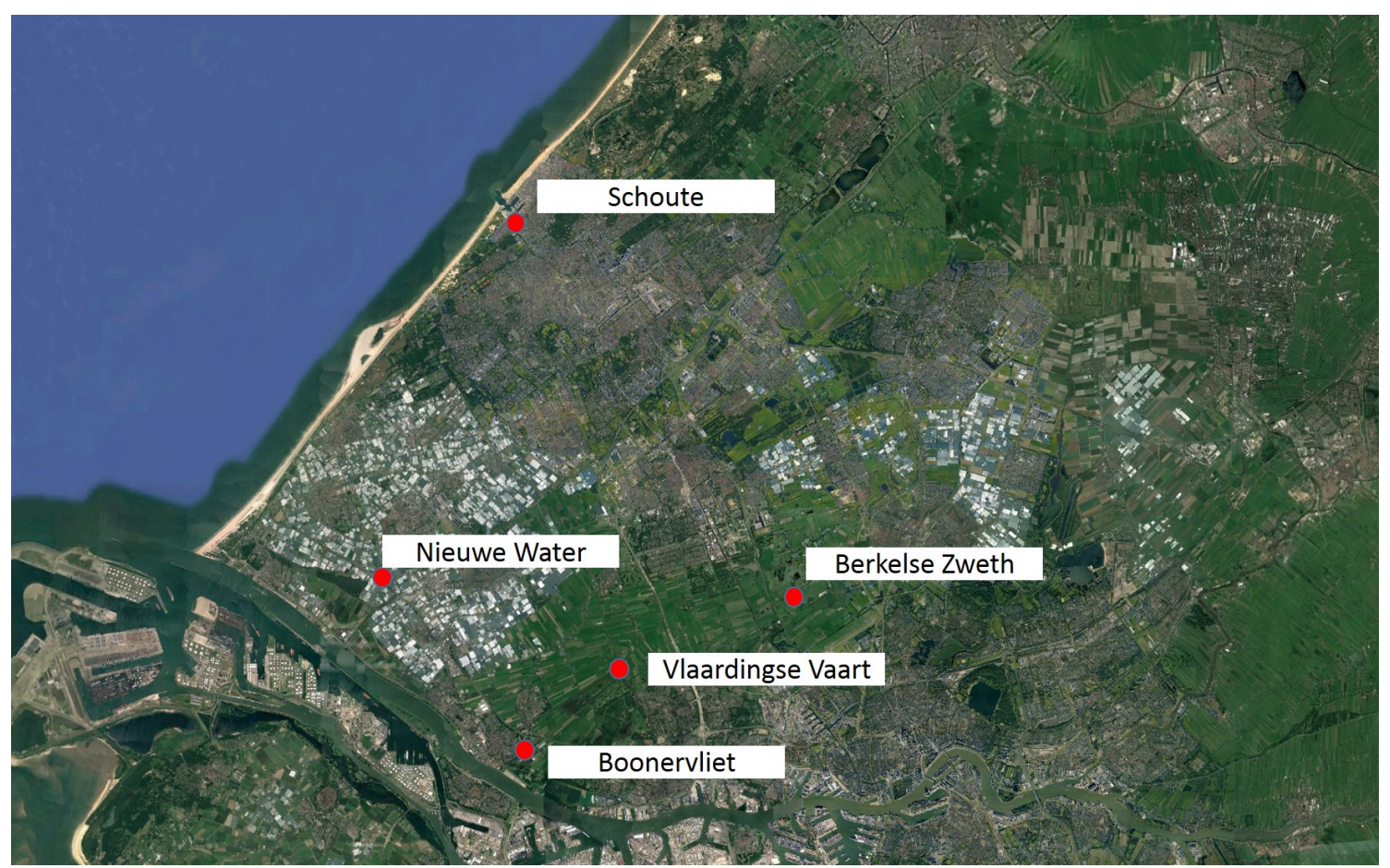

Figuur 1. De vijf deelgebieden waar het onderzoek is uitgevoerd.

Op elke locatie zijn vier fuiken geplaatst. De monitoring in 2020 is gestart op 17 april 2020 met 20 fuiken en geëindigd op 29 mei 2020. De fuiken zijn in de vangstperiode twee keer verplaatst met de gedachte dat rode aal soms zeer lokaal actief is en de kans op (nieuwe) terugvangsten dan groter is. De fuiken zijn om de drie dagen gelicht: 20, 23, 26 en 29 april, 3, 5, 8, 11, 14, 17, 20, 23, 26 en 29 mei 2020. In totaal zijn er 14 lichtingen uitgevoerd. Fuiklocaties (coördinaten) zijn gegeven in de appendix.

\subsection{Werkzaamheden en diefstal fuiken 2020}

Op 3 mei konden de fuiken in het Verversingskanaal niet worden gelicht, schoon gespoten en verplaatst, omdat de toegangsweg naar het gemaal (en de boot) was geblokkeerd vanwege rioleringswerkzaamheden door gemeente Den Haag.

Op 5 mei is geconstateerd dat in het Nieuwe Water twee fuiken waren gestolen. Daarna een reservefuik ingezet die aan boord was. Op de andere locatie waar de fuik miste kon geen fuik worden gezet.

Op 8 mei is geconstateerd in het Oranjekanaal nabij Nieuwe Water dat één fuik was gelicht en het informatiebordje van HHD t.b.v. het onderzoek kapot was gemaakt door derden. In het Nieuwe Water zijn de twee resterende fuiken gestolen en informatiebordjes elders in het Nieuwe Water teruggevonden. Door de diefstal van in totaal vier fuiken in het Nieuwe Water én het vandalisme is besloten om het rode aalonderzoek in het Nieuwe Water, in ieder geval dit jaar (2020), te stoppen. Het onderzoek heeft daar tot dan drie terugvangsten opgeleverd.

Op 17 mei is geconstateerd dat op het Boonervliet één fuik is gestolen. Hierdoor worden gegevens gemist van één lichting. De fuik is vervangen.

Op 23 mei is in het Verversingskanaal geconstateerd dat er drie fuiken (fuik nummer $1 \mathrm{t} / \mathrm{m} 3$ ) gestolen waren. Later op de dag zijn er wel weer 3 nieuwe fuiken geplaatst. Er worden daarmee vangsten gemist van 23 mei. 


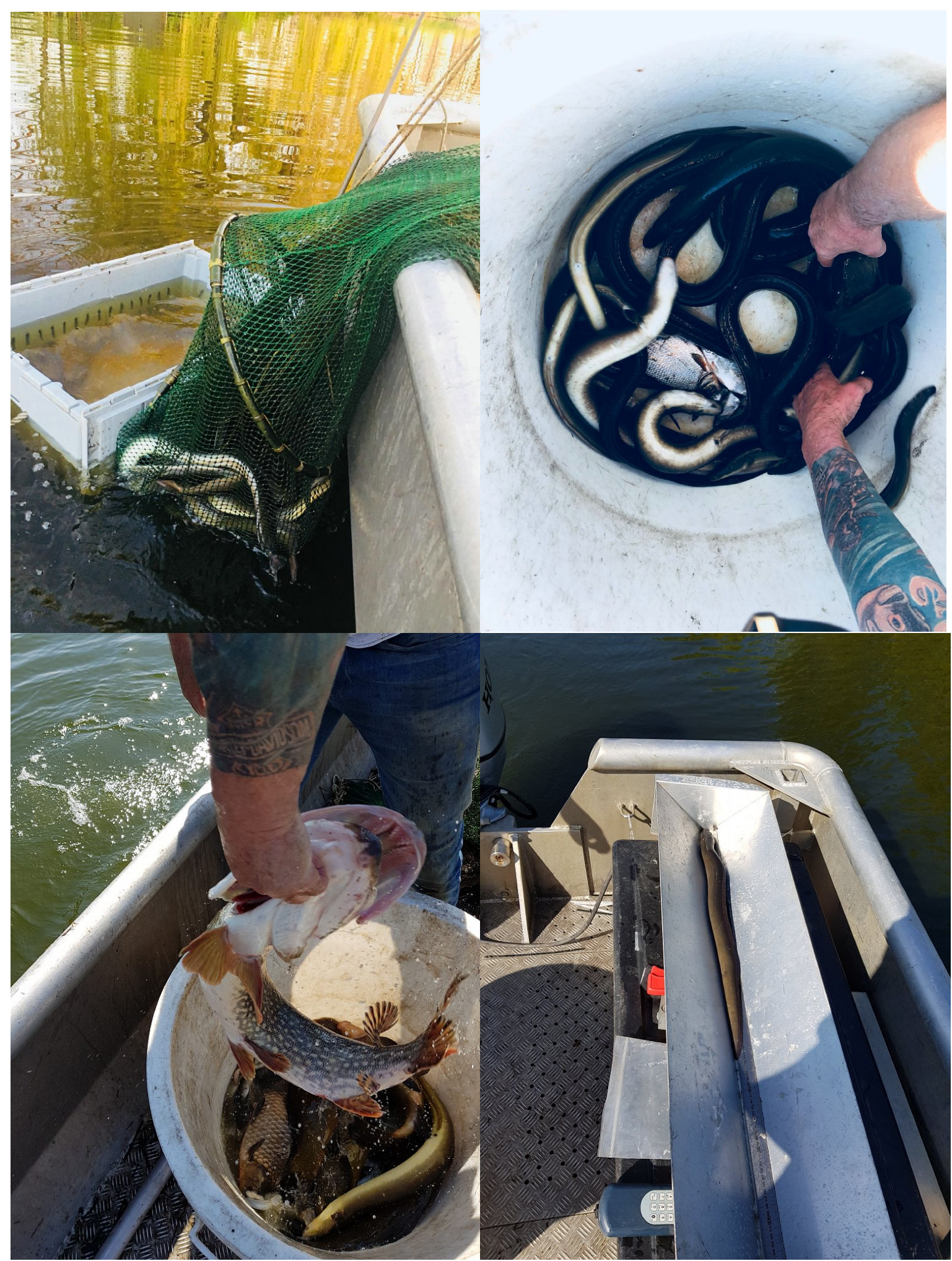

Foto 1-4. Foto's van het veldwerk. Linksboven: vangst wordt opgehaald uit een fuik. Rechtsboven: vangst wordt gesorteerd en gescand op terugvangsten. Linksonder: bijvangst wordt direct teruggezet (hier een snoek en een giebel). Rechtsonder: rode aal wordt verdoofd opgemeten in een aalgoot. (Foto's uit 2019) 


\section{Resultaten}

\subsection{Terugvangsten}

In totaal zijn tot nu toe van de 1008 gemerkte rode alen 246 (24.4\%) unieke terugvangsten gedaan (Tabel 1). Met de alen die meerdere keren zijn teruggevangen zijn er in totaal 296 groeijaren gemeten (van de 246 unieke alen). Het overgrote deel van de gemerkte alen $21.4 \% \quad(n=216)$ is één keer teruggevangen (Tabel 2), gevolgd door tweemaal terugvangst $(6.8 \%, n=69)$, driemaal terugvangst $(3.2 \%, n=32)$ en viermaal $(1.6 \%, n=16)$. In totaal zijn drie alen meer dan 10 keer gevangen $(9,10$ en 12 keer terugvangst). Het grootste terugvangpercentage is in de Boonervliet en Vlaardingse Vaart met $27.9 \%$. Het laagste is in het Nieuwe Water met $5.5 \%$.

Tabel 1. Aantal individuele terugvangsten per jaar opgedeeld indien de alen enkel in één of meerdere jaren zijn teruggevangen. Tevens het aantal 'groeijaren' waarover de gemiddelde groeisnelheid wordt bepaald. Een 'groeijaar' is gedefinieerd als het verschil in lengte $(\mathrm{mm})$ tussen vangsten in circa 1 jaar tijd. Sommige alen hebben meerdere groeijaren indien zij in meerdere jaren zijn teruggevangen.

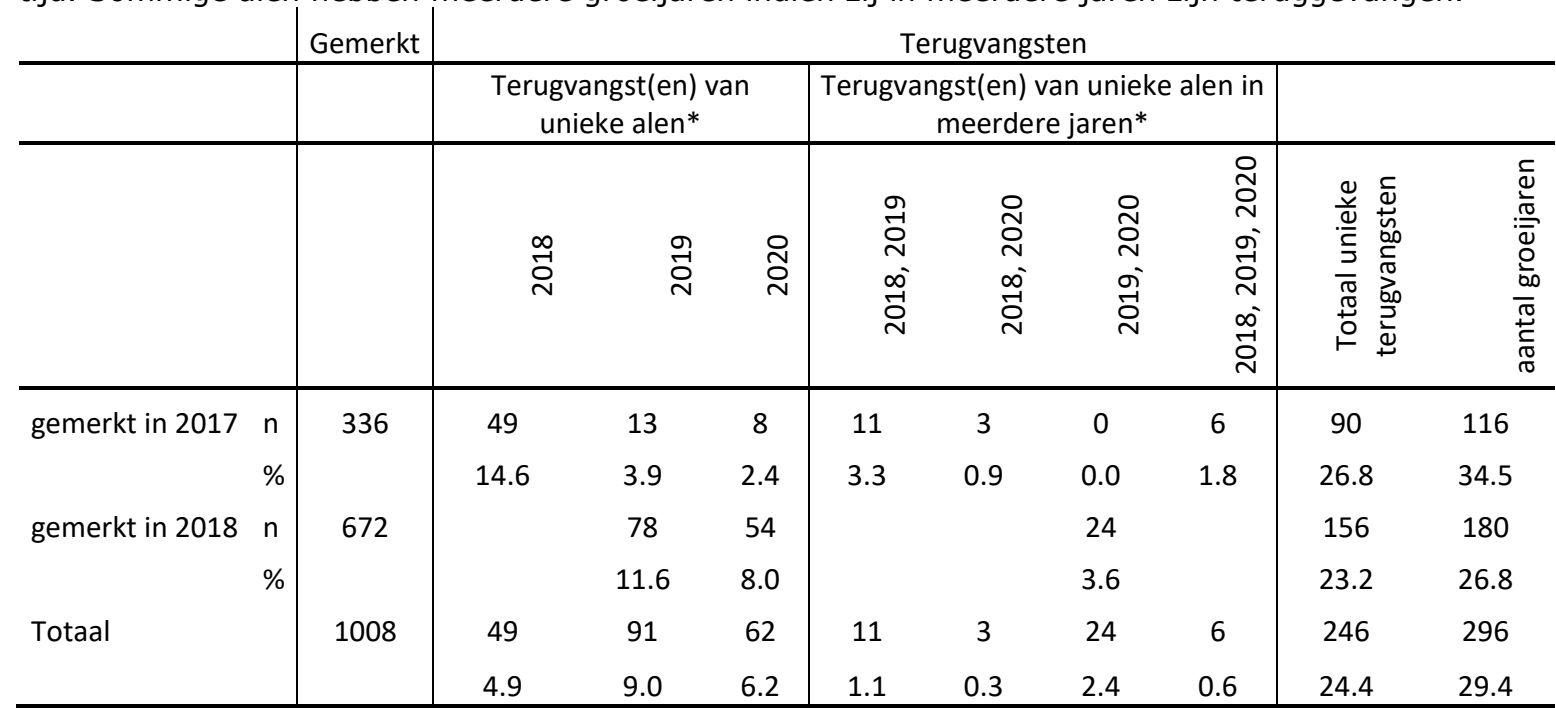

* In werkelijkheid kan een aal binnen 1 jaar meerdere malen teruggevangen worden. Dit is niet opgenomen in deze tabel. Eén of meerdere vangsten binnen 1 jaar wordt gezien als 1 unieke terugvangst. 
Tabel 2. Totaal aantal terugvangsten over alle onderzoeksjaren (2017-2020) per gebied. BV = Boonervliet, $\mathrm{VV}=$ Vlaardingse Vaart, $\mathrm{BZ}=$ Berkelse Zweth, $\mathrm{NW}=$ Nieuwe Water, VK= Verversingskanaal.

aantal keer teruggevangen (2017-2020)

\begin{tabular}{|c|c|c|c|c|c|c|c|c|c|c|c|c|c|c|c|}
\hline & & \\
\hline & & gemerkt & 1 & 2 & 3 & 4 & 5 & 6 & 7 & 8 & 9 & 10 & 11 & 12 & totaal \\
\hline \multirow[t]{2}{*}{ BO_VV } & $\mathrm{n}$ & 596 & 113 & 32 & 12 & 7 & 1 & & 1 & & & & & & 166 \\
\hline & $\%$ & & 19.0 & 5.4 & 2.0 & 1.2 & 0.2 & & 0.2 & & & & & & 27.9 \\
\hline \multirow[t]{2}{*}{$B Z$} & $n$ & 214 & 49 & 18 & 8 & 5 & 2 & & & & & & & & 82 \\
\hline & $\%$ & & 22.9 & 8.4 & 3.7 & 2.3 & 0.9 & & & & & & & & 38.3 \\
\hline \multirow[t]{2}{*}{ NW } & $n$ & 95 & 24 & 7 & 1 & 1 & & & & & & & & & 33 \\
\hline & $\%$ & & 25.3 & 7.4 & 1.1 & 1.1 & & & & & & & & & 34.7 \\
\hline \multirow[t]{2}{*}{ VK } & $\mathrm{n}$ & 103 & 30 & 12 & 11 & 3 & 4 & 4 & 1 & 1 & 1 & 1 & & 1 & 69 \\
\hline & $\%$ & & 29.1 & 11.7 & 10.7 & 2.9 & 3.9 & 3.9 & 1.0 & 1.0 & 1.0 & 1.0 & & 1.0 & 67.0 \\
\hline \multirow[t]{2}{*}{ Totaal } & $\mathrm{n}$ & 1008 & 216 & 69 & 32 & 16 & 7 & 4 & 2 & 1 & 1 & 1 & & 1 & $350^{*}$ \\
\hline & $\%$ & & 21.4 & 6.8 & 3.2 & 1.6 & 0.7 & 0.4 & 0.2 & 0.1 & 0.1 & 0.1 & & 0.1 & 34.7 \\
\hline
\end{tabular}

*Overzicht niet geheel kloppend, omdat van aal \#942046 het onduidelijk is of deze op 13 mei 2018 juist is genoteerd als vangst op het Berkelse Zweth. Eerder op 4 en 10 mei 2018 (en later op 29 april 2019) is een aal met hetzelfde merk op de Boonervliet gevangen. Logischerwijs zal de notatie op 13 mei 2018 een foutieve notatie betreffen, temeer omdat het daar staat genoteerd als een nieuw gemerkte aal.

Naast de gemerkte rode aalvangsten zijn in 2020 ook 835 ongemerkte rode alen gevangen en 54 ongemerkte schieralen. Van twee gemerkte alen was aangemerkt dat dit een schieraal betrof (\#941311 en \#941444). In 2019 was dit ook het geval met \#941413. Deze laatste aal is in 2020 echter nogmaals teruggevangen en is dus niet uitgetrokken. Daarnaast zijn in de fuiken niet alleen alen gevangen, maar ook bijvangsten zoals grote zeelt, brasem, giebel en snoek. Aan deze bijvangsten wordt in dit onderzoek geen aandacht besteed. 


\subsection{Lengtemetingen en groeisnelheid}

De groeisnelheid over alle onderzoeksjaren en alle gebieden van de vissen die zijn teruggevangen, ligt op $41.7 \mathrm{~mm}$ per jaar en er is variatie tussen de gebieden. Op basis van de teruggekoppelde data is de gemiddelde groeisnelheid bij het Nieuwe Water het hoogst met $59.8 \mathrm{~mm}$ per jaar (Figuur 2). In het jaar 2020 zijn in dit gebied slechts drie alen teruggevangen. De laagste gemiddelde groei wordt gemeten in het Verversingskanaal (31.3 mm/jaar), gevolgd door het Boonervliet/Vlaardingse Vaart (40.7 mm/jaar) en Berkelse Zweth ( $50.9 \mathrm{~mm} / \mathrm{jaar}$ ). Er zijn binnen dit onderzoek diverse alen gevonden die over 1,2 en 3 jaar geen groei realiseerden. Dit heeft invloed op de gemiddelde groei per gebied. Er is geen verschil in groeisnelheid tussen jaren (Figuur 3). Met andere woorden de groei tussen 2018, 2019 en 2020 is vergelijkbaar.

\section{groeisnelheid rode aal $\mathrm{mm} / \mathrm{jaar}$}

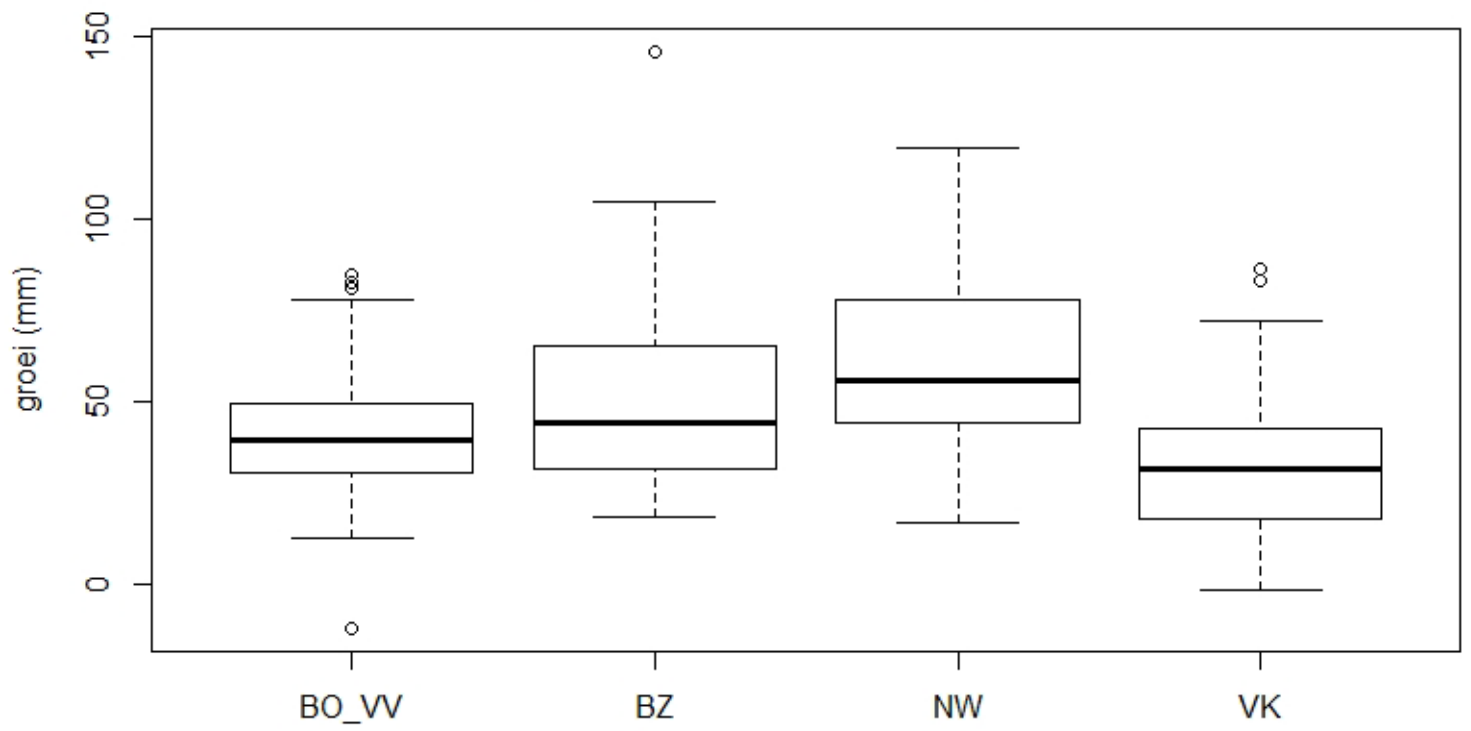

Figuur 2. Groeisnelheden per gebied ( $\mathrm{mm} /$ jaar). De groeisnelheid per teruggevangen aal wordt bepaald door het verschil in lengte $(\mathrm{mm})$ en tijdverschil.

\section{groeisnelheid rode aal $\mathrm{mm} / \mathrm{jaar}$}

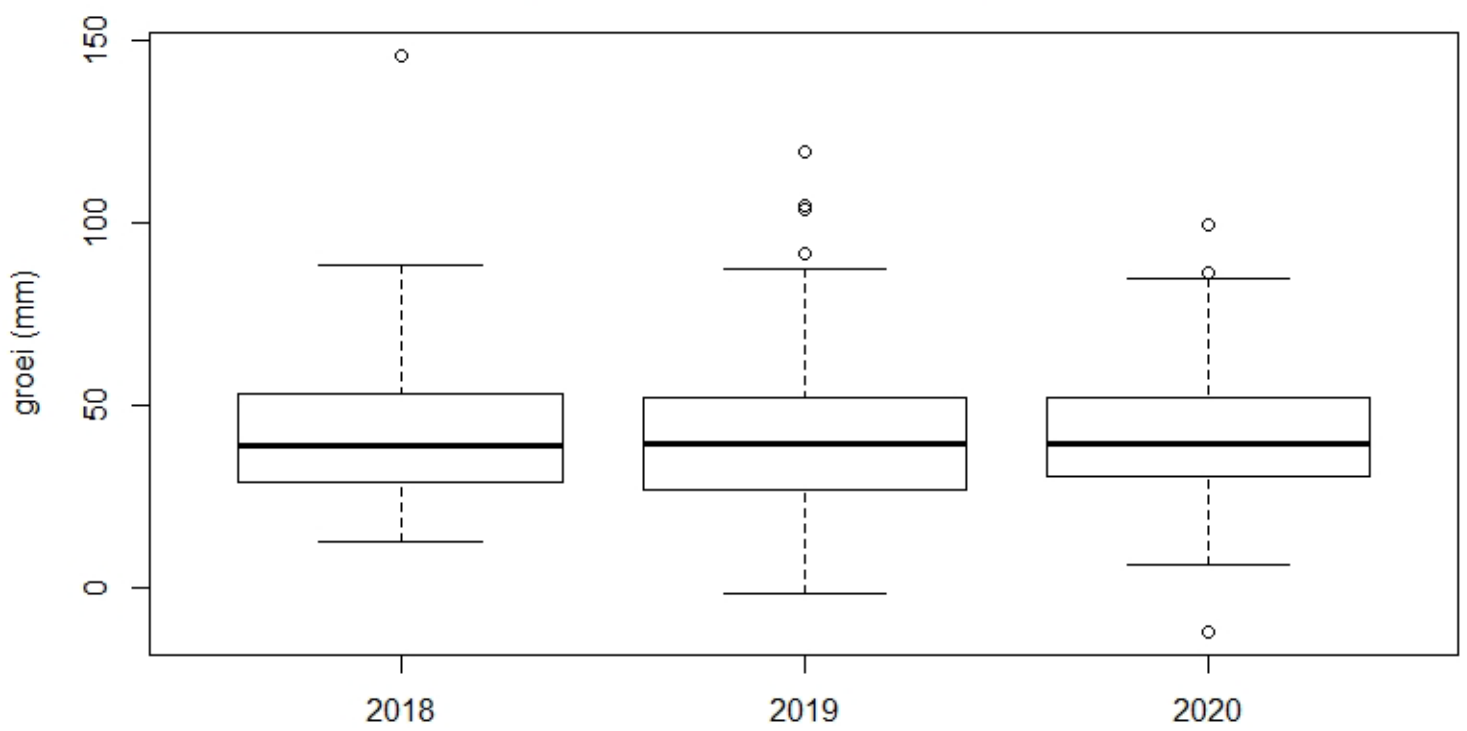

Figuur 3. Groeisnelheden per jaar ( $\mathrm{mm} /$ jaar). De groeisnelheid per teruggevangen aal wordt bepaald door het verschil in lengte $(\mathrm{mm})$ en tijdverschil. 
Naast de spreiding van groeigegevens per jaar, is dit jaar ook gekeken naar de relatieve groei. Deze groei is bepaald door de relative groei te berekenen t.o.v. de startlengte. Bij meerdere terugvangsten binnen één jaar is eerst een gemiddelde lengte bepaald met een gemiddelde tijd tussen merken en terugvangst. Hierdoor ontstaat één waarde per seizoen. $\mathrm{Er}$ is een grote variatie zichtbaar tussen de individuele alen (Figuur 4 en Figuur 5).

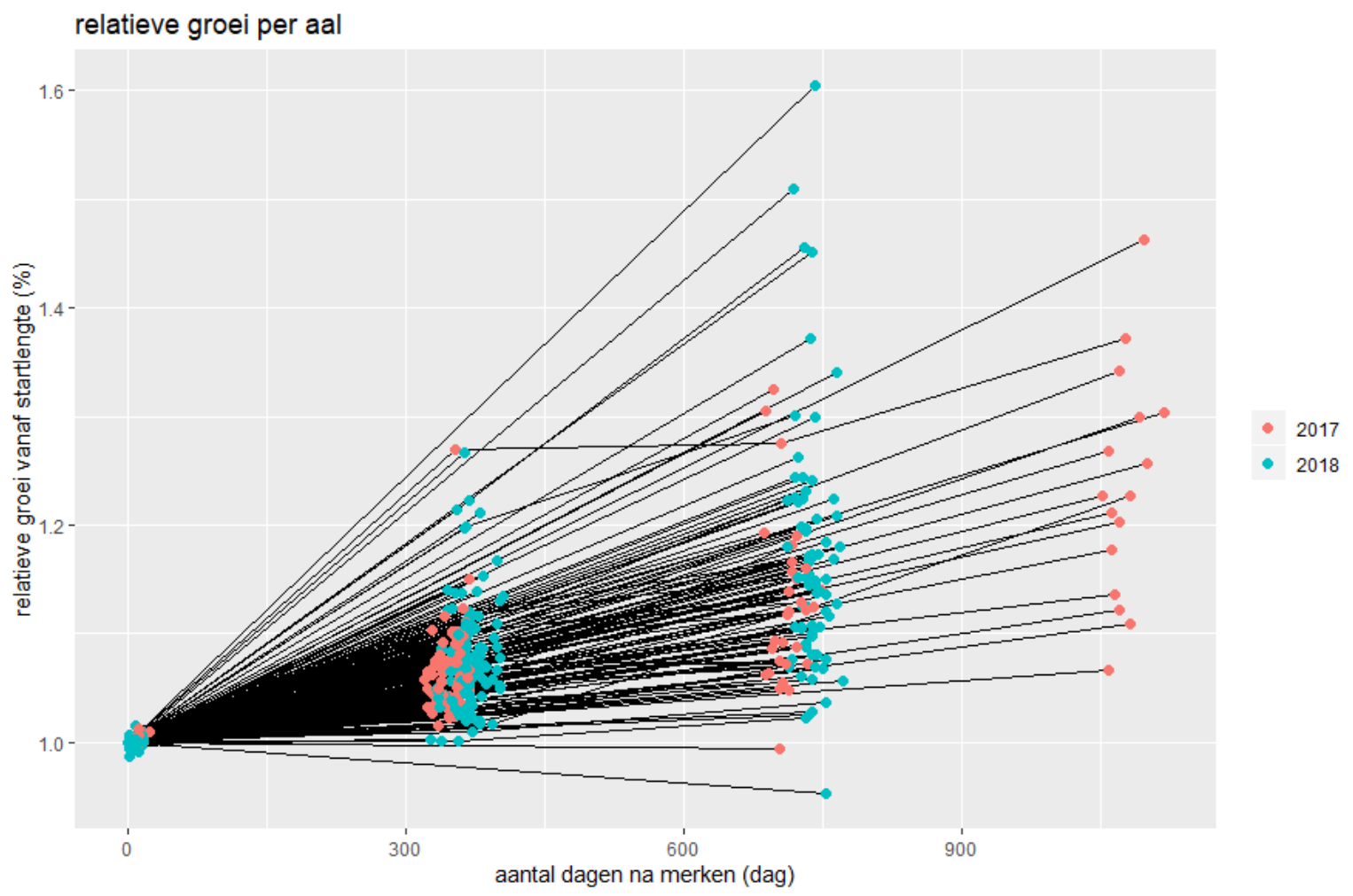

Figuur 4. Relatieve groei ten opzichte van het moment van merken. Er is onderscheid gemaakt in de groep die in 2017 is gemerkt en de groep die in 2018 is gemerkt. Negatieve waarden zijn mogelijk het gevolg van foutieve notaties.

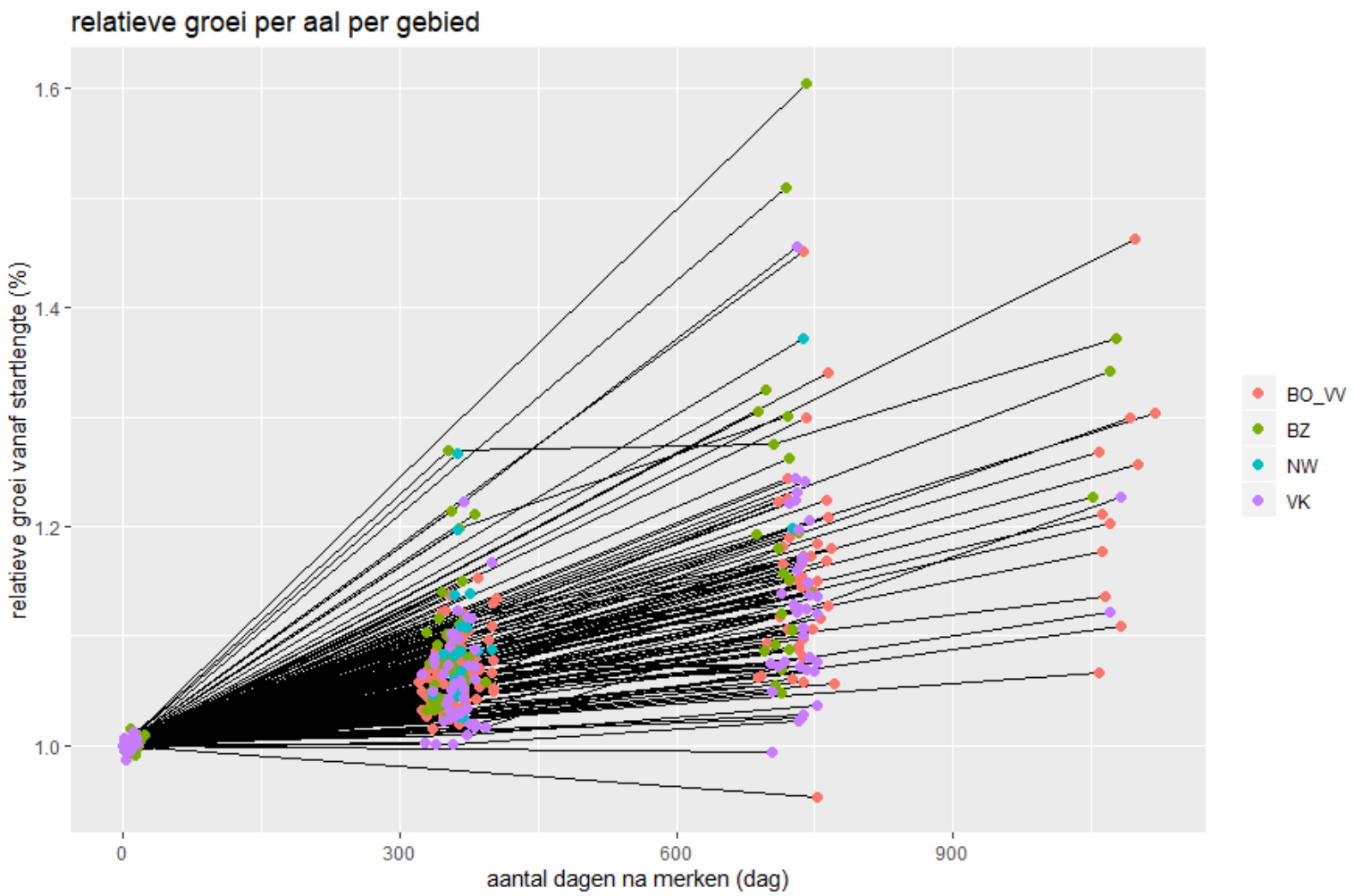

Figuur 5. Relatieve groei ten opzichte van het moment van merken. Er is onderscheid gemaakt per gebied in kleuren. Negatieve waarden zijn mogelijk het gevolg van foutieve notaties. 
Binnen deze datarapportage worden enkele interessante voorbeelden gegeven van lengteverschil in de tijd (Figuren 6-8). In sommige gevallen zijn alen in alle onderzoeksjaren (terug)gevangen en laten een min of meer stabiele groei zien (Figuur 6 ). In andere gevallen is de groei miniem met minder dan $4 \mathrm{~cm}$ over 3 of 4 jaren (Figuur 7). Dit betreffen mogelijk mannetjes die zijn uitgegroeid en niet groter worden dan circa $50 \mathrm{~cm}$. Sommige alen worden veelvuldig teruggevangen (Figuur 8).
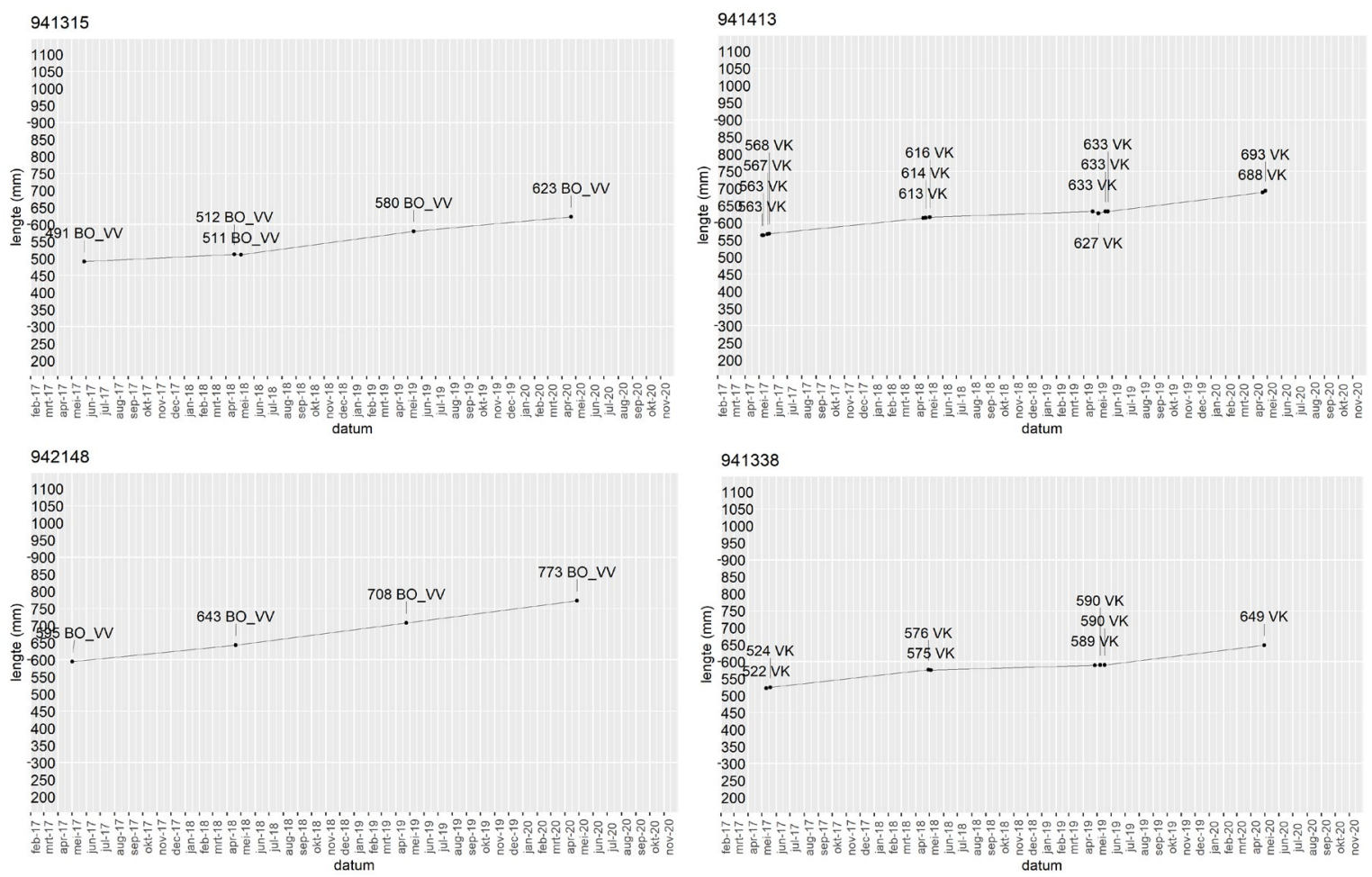

Figuur 6. Enkele voorbeelden van alen uit de groep van 2017 die in alle 4 de jaren zijn gemeten (2017-2020).
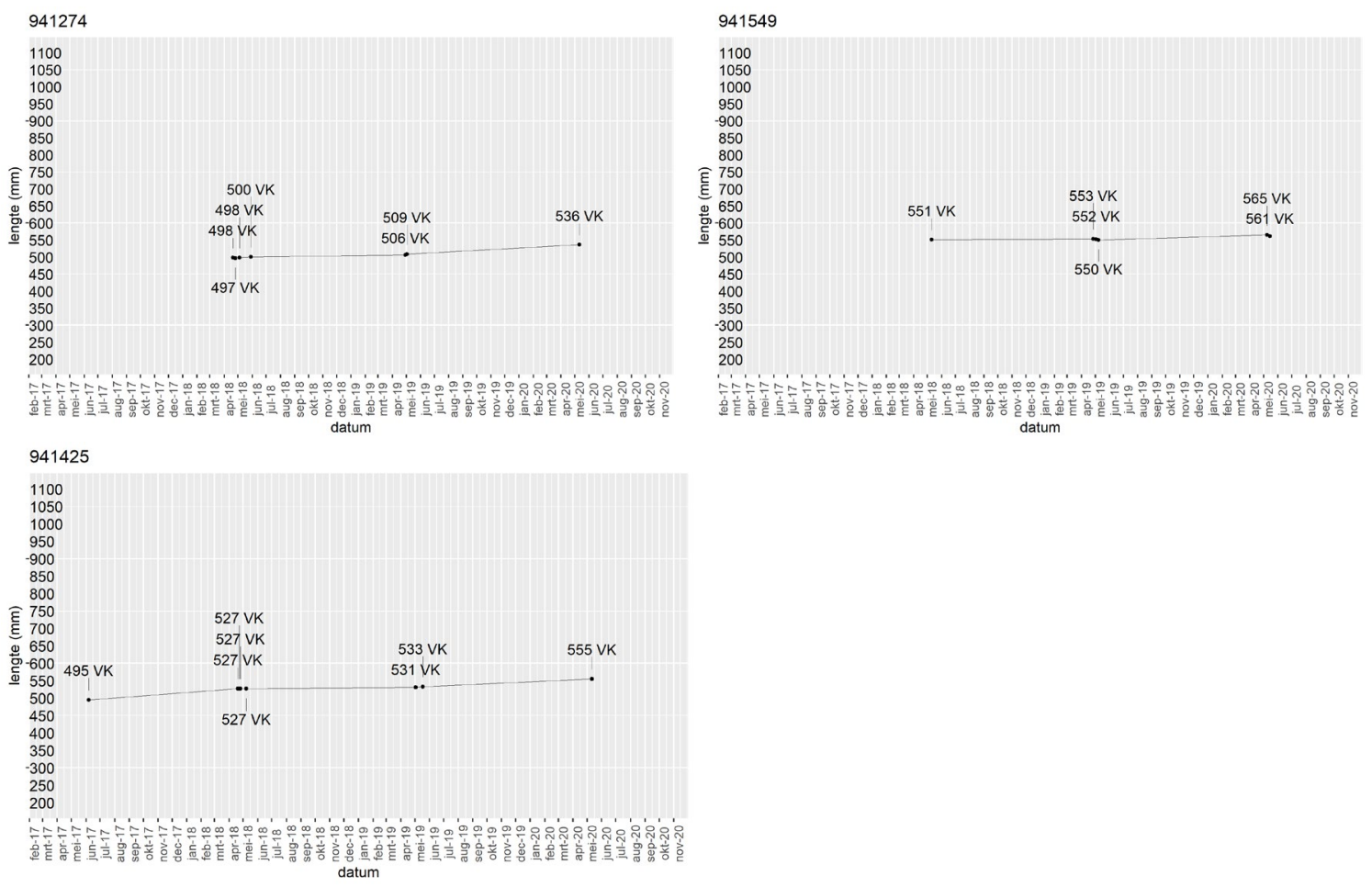

Figuur 7. Enkele voorbeelden van alen die nauwelijk groei laten zien ( $<4 \mathrm{~cm}$ over drie/vier jaar). Mogelijk mannetjes die uitgegroeid zijn. 


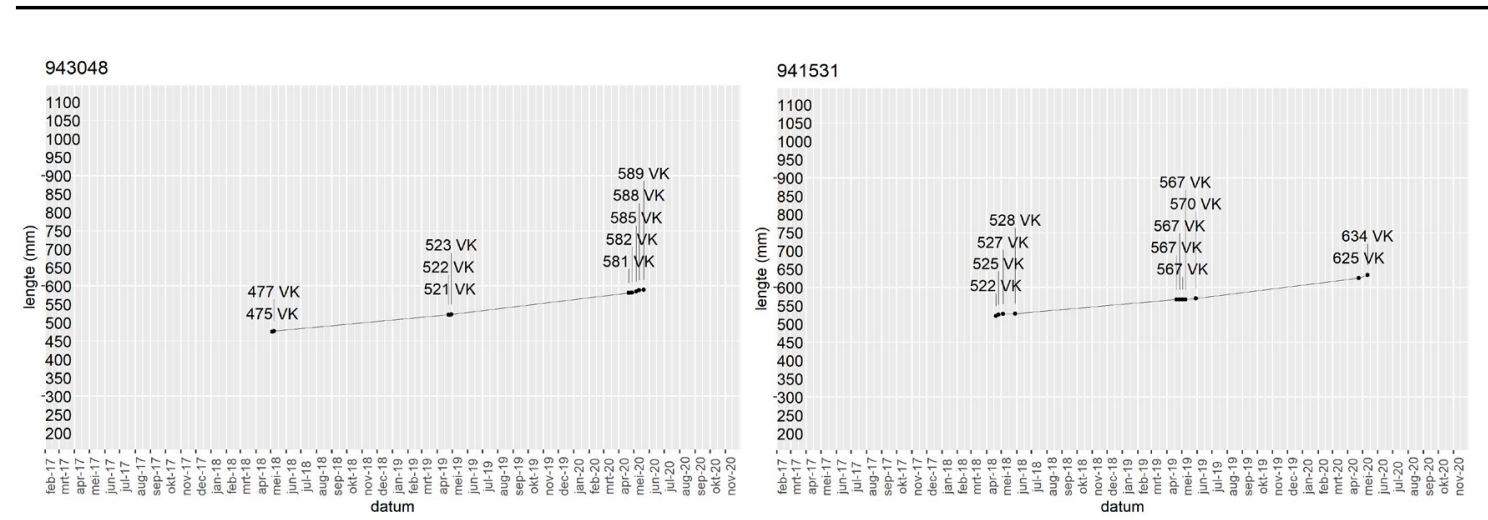

Figuur 8. Twee alen die veelvuldig worden teruggevangen en een vergelijkbare groei laten zien van circa $11 \mathrm{~cm}$ over twee jaar. 


\section{$4 \quad$ Conclusies en aanbevelingen}

Het doel van de rapportage is een weergave te geven van de gemiddelde groei van rode aal in de diverse gebieden. In totaal zijn in 202096 verschillende alen teruggevangen van de 1008 gemerkte rode alen (9.5\%). Veertien alen zijn twee keer gevangen, één aal drie keer, drie alen vier keer en één aal vijf keer en één aal zes gevangen binnen het onderzoek van 2020. Het totaal aantal terugvangsten in 2020 komt daarmee op 130 stuks (BO/VV: 55 stuks, BZ: 17 stuks, NW: 3 stuks en VK: 55 stuks).

Er zijn tot nu in totaal 296 groeijaren vastgesteld. De groeisnelheid over alle onderzoeksjaren van de vissen die zijn teruggevangen ligt rond de $41.7 \mathrm{~mm}$ per jaar, maar er is variatie tussen de gebieden. Op basis van de teruggekoppelde data is de gemiddelde groeisnelheid over alle jaren bij het Nieuwe Water het hoogst (59.8mm per jaar). In het jaar 2020 zijn in dit gebied slechts drie alen teruggevangen. De laagste gemiddelde groei over alle jaren wordt gemeten in het Verversingskanaal (31.3 mm/jaar), gevolgd door de Boonervliet/Vlaardingse Vaart $(40.7 \mathrm{~mm} / \mathrm{jaar}$ ) en Berkelse Zweth (50.9 mm/jaar). Er zijn binnen dit onderzoek alen gevonden die over 1, 2 en 3 jaar geen groei realiseerden, dit betreffen mogelijk uitgegroeide mannelijke alen.

\section{Aanbevelingen}

Aanbevolen wordt om net als voorgaande jaren de alen in verdoofde toestand te meten. Op deze manier blijft de groei vergelijkbaar tussen de jaren.

In het jaar 2020 heeft het onderzoek hinder ondervonden van diefstal van fuiken. Zeker op locaties met relatief weinig terugvangsten, het Verversingskanaal en het Nieuwe Water, is dat schadelijk voor het onderzoek. Aanbevolen wordt om hier vanuit het Hoogheemraadschap aandacht aan te geven voorafgaand aan het onderzoek in 2021. De variatie in groei tussen de alen is groot en daarom is het wenselijk om de trefkans van terugvangsten te optimaliseren door het plaatsen van voldoende fuiken in het onderzoeksgebied. 


\section{$5 \quad$ Kwaliteitsborging}

Wageningen Marine Research beschikt over een ISO 9001:2015 gecertificeerd kwaliteitsmanagementsysteem. Dit certificaat is geldig tot 15 december 2018. De organisatie is gecertificeerd sinds 27 februari 2001. De certificering is uitgevoerd door DNV GL.

Het chemisch laboratorium te IJmuiden beschikt over een NEN-EN-ISO/IEC 17025:2005 accreditatie voor testlaboratoria met nummer L097. Deze accreditatie is geldig tot 1 april 2021 en is voor het eerst verleend op 27 maart 1997; deze accreditatie is verleend door de Raad voor Accreditatie. Het chemisch laboratorium heeft hierdoor aangetoond in staat te zijn op technisch bekwame wijze valide resultaten te leveren en te werken volgens de ISO17025 norm. De scope (L097) met de geaccrediteerde analysemethoden is te vinden op de website van de Raad voor Accreditatie (www.rva.nl).

Op grond van deze accreditatie is het kwaliteitskenmerk $\mathrm{Q}$ toegekend aan de resultaten van die componenten die op de scope staan vermeld, mits aan alle kwaliteitseisen is voldaan. Het kwaliteitskenmerk Q staat vermeld in de tabellen met de onderzoeksresultaten. Indien het kwaliteitskenmerk $Q$ niet staat vermeld is de reden hiervan vermeld.

De kwaliteit van de analysemethoden wordt op verschillende manieren gewaarborgd. De juistheid van de analysemethoden wordt regelmatig getoetst door deelname aan ringonderzoeken waaronder die georganiseerd door QUASIMEME. Indien geen ringonderzoek voorhanden is, wordt een tweede lijnscontrole uitgevoerd. Tevens wordt bij iedere meetserie een eerstelijnscontrole uitgevoerd. Naast de lijnscontroles wordende volgende algemene kwaliteitscontroles uitgevoerd:

- Blanco onderzoek.

- Terugvinding (recovery).

- $\quad$ Interne standaard voor borging opwerkmethode.

- Injectie standard.

- Gevoeligheid.

Bovenstaande controles staan beschreven in Wageningen Marine Research werkvoorschrift ISW 2.10.2.105.

Indien gewenst kunnen gegevens met betrekking tot de prestatiekenmerken van de analysemethoden bij het chemisch laboratorium worden opgevraagd.

Indien sprake is van onbeheerste kwaliteit worden passende maatregelen genomen. 


\section{Literatuur}

Griffioen, A. B., and K. Schilder. 2018. Aalonderzoeken Hoogheemraadschap van Delfland: groei en verspreiding van rode aal (Anguilla anguilla) 2018. Wageningen Marine Research, IJmuiden.

Griffioen, A. B., M. E. Schiphouwer, H. V. Winter, and S. Ploegaert. 2018 Aalonderzoeken Hoogheemraadschap van Delfland: efficiëntie van glasaalintrek bij gemaal Schoute Wageningen Marine Research report C007.18. 


\section{Verantwoording}

Rapport C101/20

Projectnummer: 4316100192

Dit rapport is met grote zorgvuldigheid tot stand gekomen. De wetenschappelijke kwaliteit is intern getoetst door een collega-onderzoeker en het verantwoordelijk lid van het managementteam van Wageningen Marine Research

Akkoord:

Dr. JC van Rijssel

Onderzoeker

Handtekening:

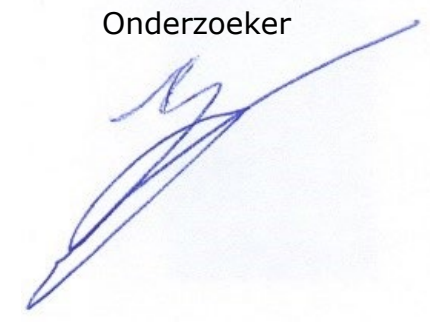

Datum:

18 november 2020

Akkoord:

Drs. J. Asjes

Manager Integratie

Handtekening:

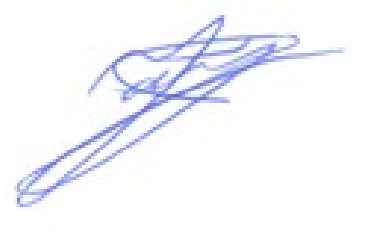

Datum:

18 november 2020 


\section{Bijlage 1 Lengte frequentie alen}
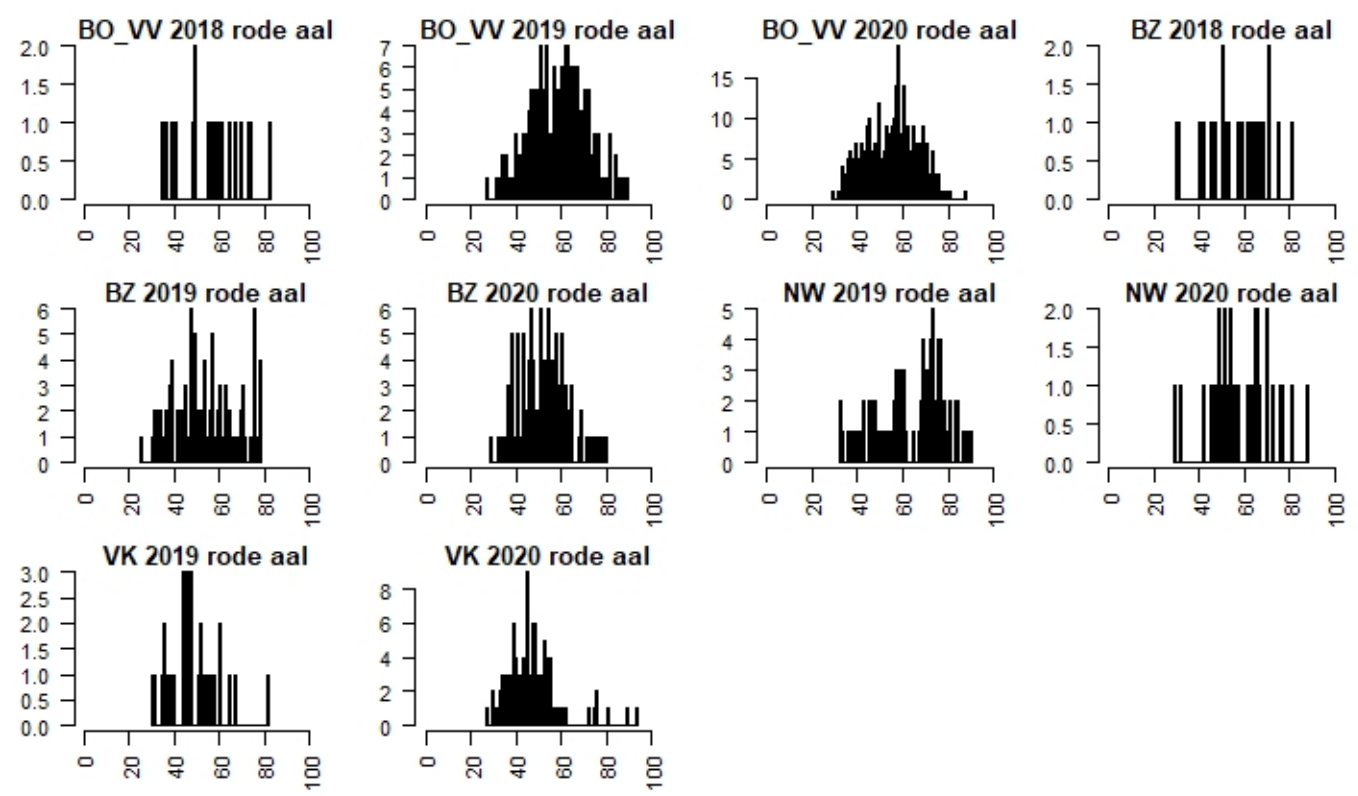

Figuur A. Lengte frequentie van rode alen die zijn gevangen maar geen merk hadden.
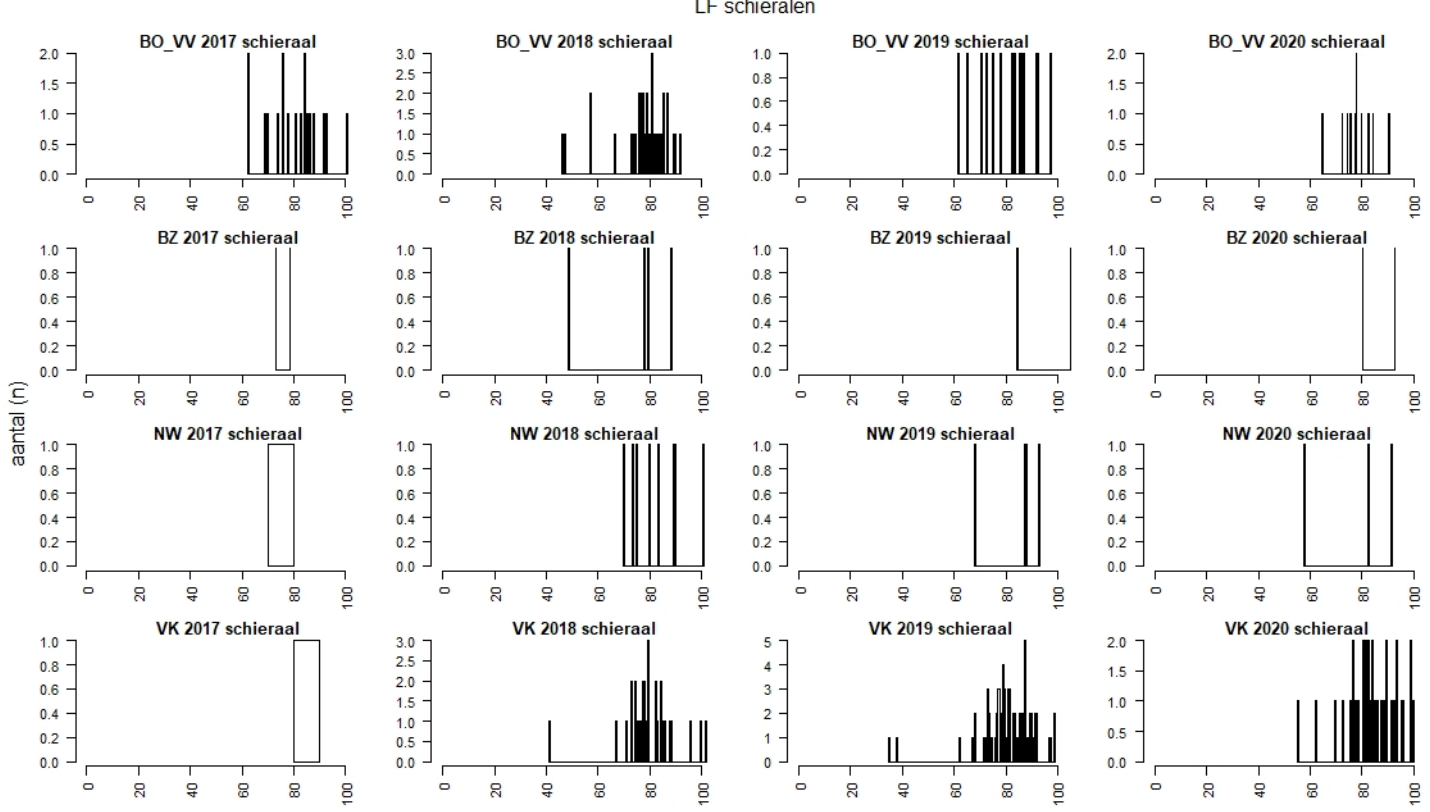

lengte $(\mathrm{cm})$

Figuur B. Lengte frequentie van schieralen die zijn gevangen maar geen merk hadden. 


\section{Bijlage 2 Coördinaten fuiklocaties}

\begin{tabular}{|c|c|c|c|c|}
\hline \multirow{2}{*}{$\begin{array}{l}\text { Datum } \\
17 / \text { apr/20 }\end{array}$} & \multirow{2}{*}{$\begin{array}{l}\text { Locatie } \\
\text { Boonervliet/Vlaardingse Vaart }\end{array}$} & \multicolumn{2}{|c|}{ fuiknr. X-coordinaat } & \multirow{2}{*}{$\begin{array}{r}\text { Y-coordinaat } \\
437419\end{array}$} \\
\hline & & $\mathrm{BV} / \mathrm{VV} 1$ & 078409 & \\
\hline & Boonervliet/Vlaardingse Vaart & $\mathrm{BV} / \mathrm{NV} 2$ & 078278 & 437320 \\
\hline & Boonervliet/Vlaardingse Vaart & $\mathrm{BV} / \mathrm{NV} 3$ & 078640 & 437595 \\
\hline & Boonervliet/Vlaardingse Vaart & $\mathrm{BV} / \mathrm{VV} 4$ & 079277 & 438120 \\
\hline & Boonervliet/Vlaardingse Vaart & BV/VV 5 & 080158 & 438857 \\
\hline & Boonervliet/Vlaardingse Vaart & BV/NV 6 & 080462 & 439184 \\
\hline & Boonervliet/Vlaardingse Vaart & $\mathrm{BV} / \mathrm{VV} 7$ & 081302 & 439703 \\
\hline & Boonervliet/Vlaardingese Vaart & BV/VV 8 & 081913 & 439725 \\
\hline & Oranjekanaal/Nieuwe water & OK/NW 1 & 073246 & 442931 \\
\hline & Oranjekanaal/Nieuwe water & OK/NW 2 & 073550 & 443211 \\
\hline & Oranjekanaal/Nieuwe water & OK/NW 3 & 073201 & 443480 \\
\hline & Oranjekanaal/Nieuwe water & OK/NW 4 & 072979 & 443832 \\
\hline & Berkelsche Zweth & BZ 1 & 089053 & 443514 \\
\hline & Berkelsche Zweth & BZ 2 & 088882 & 443410 \\
\hline & Berkelsche Zweth & BZ 3 & 088690 & 443275 \\
\hline & Berkelsche Zweth & BZ 4 & 088463 & 443148 \\
\hline & Verversingskanaal & VK 1 & 078316 & 456232 \\
\hline & Verversingskanaal & VK 2 & 078419 & 456155 \\
\hline & Verversingskanaal & VK 3 & 078468 & 456054 \\
\hline & Verversingskanaal & VK 4 & 078529 & 456014 \\
\hline 3/mei & Berkelsche Zweth & BZ 1 & 088965 & 443454 \\
\hline & Berkelsche Zweth & BZ 2 & 088619 & 443240 \\
\hline & Berkelsche Zweth & BZ 3 & 088270 & 443017 \\
\hline & Berkelsche Zweth & BZ 4 & 088114 & 442924 \\
\hline & Boonervliet/Vlaardingse Vaart & $\mathrm{BV} / \mathrm{NV} 1$ & 078342 & 437373 \\
\hline & Boonervliet/Vlaardingse Vaart & $\mathrm{BV} / \mathrm{NV} 2$ & 078122 & 437205 \\
\hline & Boonervliet/Vlaardingse Vaart & BV/NV 3 & 078901 & 437795 \\
\hline & Boonervliet/Vlaardingse Vaart & $\mathrm{BV} / \mathrm{NV} 4$ & 079527 & 430317 \\
\hline & Boonervliet/Vlaardingse Vaart & BV/VV 5 & 080337 & 438911 \\
\hline & Boonervliet/Vlaardingse Vaart & BV/NV 6 & 080343 & 439286 \\
\hline & Boonervliet/Vlaardingse Vaart & $\mathrm{BV} / \mathrm{NV} 7$ & 081492 & 439869 \\
\hline & Boonervliet/Vlaardingse Vaart & $\mathrm{BV} / \mathrm{NV} 8$ & 082080 & 439686 \\
\hline & Oranjekanaal/Nieuwe water & OK/NW 1 & 073435 & 443022 \\
\hline & Oranjekanaal/Nieuwe water & OK/NW 2 & 073460 & 443279 \\
\hline & Oranjekanaal/Nieuwe water & OK/NW 3 & 073083 & 443560 \\
\hline & Oranjekanaal/Nieuwe water & OK/NW 4 & 072951 & 444025 \\
\hline $5 / \mathrm{mei}$ & Verversingskanaal & VK 1 & 078368 & 456203 \\
\hline & Verversingskanaal & VK 2 & 078443 & 456081 \\
\hline & Verversingskanaal & VK 3 & 078554 & 455930 \\
\hline & Verversingskanaal & VK 4 & 078627 & 455868 \\
\hline $17 /$ mei & Verversingskanaal & VK 1 & 078383 & 456149 \\
\hline & Verversingskanaal & VK 2 & 078516 & 456027 \\
\hline & Verversingskanaal & VK 3 & 078605 & 455857 \\
\hline & Verversingskanaal & VK 4 & 078700 & 455687 \\
\hline & Berkelsche Zweth & BZ 1 & 088779 & 443339 \\
\hline & Berkelsche Zweth & BZ 2 & 088337 & 443073 \\
\hline & Berkelsche Zweth & BZ 3 & 088005 & 442840 \\
\hline & Berkelsche Zweth & BZ 4 & 087829 & 442741 \\
\hline & Boonervliet/Vlaardingse Vaart & $\mathrm{BV} / \mathrm{VV} 1$ & 077988 & 437139 \\
\hline & Boonervliet/Vlaardingse Vaart & $\mathrm{BV} / \mathrm{NV} 2$ & 079009 & 437879 \\
\hline & Boonervliet/Vlaardingse Vaart & $\mathrm{BV} / \mathrm{VV} 3$ & 079254 & 438100 \\
\hline & Boonervliet/Vlaardingse Vaart & $\mathrm{BV} / \mathrm{VV} 4$ & 080320 & 439442 \\
\hline & Boonervliet/Vlaardingse Vaart & BV/NV 5 & 080801 & 439251 \\
\hline & Boonervliet/Vlaardingse Vaart & BV/NV 6 & 081671 & 439943 \\
\hline & Boonervliet/Vlaardingse Vaart & BV/VV 7 & 081666 & 439941 \\
\hline & Boonervliet/Vlaardingse Vaart & $\mathrm{BV} / \mathrm{NV} 8$ & 082173 & 439546 \\
\hline
\end{tabular}


Wageningen Marine Research

T: +31 (0)317480900

E: marine-research@wur.nl

www.wur.nl/marine-research

Bezoekers adres:

- Ankerpark 271781 AG Den Helder

- Korringaweg 7, 4401 NT Yerseke

- Haringkade 1, 1976 CP IJmuiden
Wageningen Marine Research levert met kennis, onafhankelijk wetenschappelijk onderzoek en advies een wezenlijke bijdrage aan een duurzamer, zorgvuldiger beheer, gebruik en bescherming van de natuurlijke rijkdommen in zee-, kust- en zoetwatergebieden.

Wageningen Marine Research is onderdeel van Wageningen University \& Research. Wageningen University \& Research is het samenwerkingsverband tussen Wageningen University en Stichting Wageningen Research en heeft als missie: 'To explore the potential of nature to improve the quality of life' 